\title{
The role of pneumonectomy in thoracic surgery in the third millennium
}

In 1895, Macewen completed in multiple stages the first pneumonectomy in a patient with tubercular empyema. Further attempts with one-stage pneumonectomy had not met with success. In 1910, Kummel realised a pneumonectomy for lung cancer by clamping the pedicle (leaving the clamps in situ), but the patient died on the sixth operative day. In 1922, Hinz achieved the first individual hilar ligation, but patient succumbed on postoperative day 3. In 1930, Rudolf Nissen, in Berlin, performed in Europe the first successful left-sided pneumonectomy as a two-stage procedure. In 1933, Graham and Singer described the first effective en bloc left pneumonectomy for lung cancer, followed, in 1935, by Overholt, with the first right pneumonectomy (1). In these patients, the diagnosis had been made with radiography and pathology obtained from bronchoscopy (2). Individual suturing has initially been recommended for pneumonectomy, but Blades and Kent later applied in 1940 to lobectomy.

Moreover, indications for pneumonectomy changed over time and, currently, the widespread development of lung cancer is the first application. Indeed, pneumonectomy for inflammatory lung disease, bronchiectasis, tuberculosis, and other nonmalignant conditions is quite uncommon in modern-day medicine. However, despite many efforts, pneumonectomy remains a challenging operation, carrying many complications and anatomic and physiologic changes (3).

Pneumonectomy, therefore, cause a disability status to treat a much more severe disease (lung cancer). Undoubtedly, extensive experience with pneumonectomy has been gained along with time and with the development of thoracic surgery. Due to an improved familiarity of cardiorespiratory physiology, more and more sophisticated methods of evaluation were developed. On the other hands, there were provided reasonable guidelines for the relative risk of a patient candidate for pneumonectomy. Nevertheless, if much has been on papers, little has been learnt (3).

This series of the Shanghai Chest journal aimed to describe the risks and indications of pneumonectomies in the third millennium in the light of innovative technologies and new therapies. Also, standard, intrapericardial and extrapleural pneumonectomies have been described by outleading authors along with indications for the procedures. In this perspective, the different items are not an all-encompassing reviews, but they contain the highlights along with the essential references for additional readings.

\section{Acknowledgments}

Funding: This work was partially supported by the Italian Ministry of Health with Ricerca Corrente and 5×1,000 funds.

\section{Footnote}

Provenance and Peer Review: This article was commissioned by the editorial office, Shanghai Chest for the series "The Role of Pneumonectomy in Thoracic Surgery in The Third Millennium". The article did not undergo external peer review.

Conflicts of Interest: Both authors have completed the ICMJE uniform disclosure form (available at http://dx.doi.org/10.21037/ shc-2019-rpts-27). The series "The Role of Pneumonectomy in Thoracic Surgery in The Third Millennium" was commissioned by the editorial office without any funding or sponsorship. LB and LS both served as the unpaid Guest Editors of the series and serve as an unpaid editorial board member of Shanghai Chest from Aug 2019 to Jul 2021. The authors have no other conflicts of interest to declare.

Ethical Statement: The authors are accountable for all aspects of the work in ensuring that questions related to the accuracy or integrity of any part of the work are appropriately investigated and resolved.

Open Access Statement: This is an Open Access article distributed in accordance with the Creative Commons AttributionNonCommercial-NoDerivs 4.0 International License (CC BY-NC-ND 4.0), which permits the non-commercial replication 
and distribution of the article with the strict proviso that no changes or edits are made and the original work is properly cited (including links to both the formal publication through the relevant DOI and the license). See: https://creativecommons.org/ licenses/by-nc-nd/4.0/.

\section{References}

1. Fuentes PA. Pneumonectomy: historical perspective and prospective insight. Eur J Cardiothorac Surg 2003;23:439-45.

2. Graham EA, Singer JJ. Landmark article Oct 28, 1933. Successful removal of an entire lung for carcinoma of the bronchus. By Evarts A. Graham and J. J. Singer. JAMA 1984;251:257-60.

3. Brewer LA 3rd. Historical notes on lung cancer before and after Graham's successful pneumonectomy in 1933. Am J Surg 1982;143:650-9.

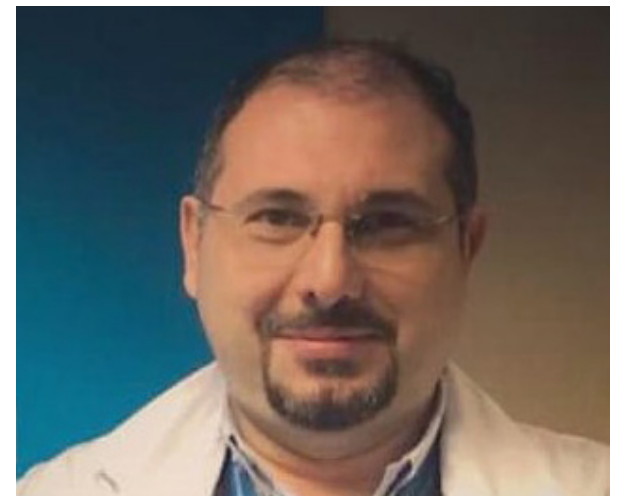

Luca Bertolaccini

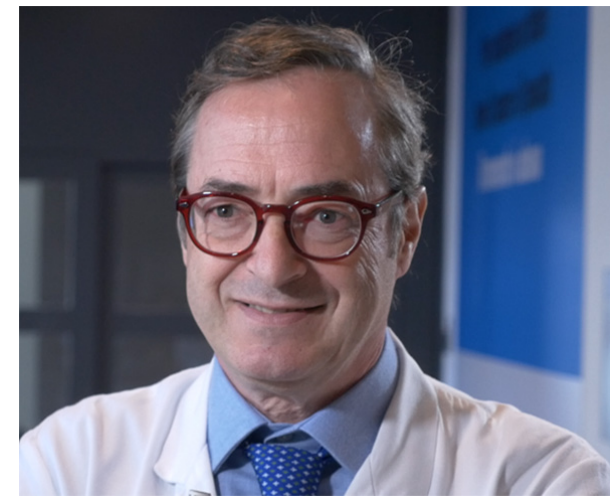

Lorenzo Spaggiari

Luca Bertolaccini ${ }^{1}, \mathbf{M D}, \mathbf{P h D}$

(Email: luca.bertolaccini@gmail.com) Lorenzo Spaggiari $^{1,2}, \mathrm{MD}, \mathrm{PhD}$

(Email: lorenzo.spaggiari@ieo.it)

${ }^{1}$ Department of Thoracic Surgery, IEO, European Institute of Oncology IRCCS, Milan, Italy;

${ }^{2}$ Department of Oncology and Hemato-Oncology, University of Milan, Milan, Italy.

Received: 25 July 2020; Accepted: 05 August 2020; Published: 10 January 2021.

doi: $10.21037 /$ shc-2019-rpts-27

View this article at: http://dx.doi.org/10.21037/shc-2019-rpts-27

doi: 10.21037/shc-2019-rpts-27

Cite this article as: Bertolaccini L, Spaggiari L. The role of pneumonectomy in thoracic surgery in the third millennium. Shanghai Chest 202 1;5:2. 